\title{
SPIRITUALITY AND CONTEXTUALITY
}

\author{
K. Waaijman ${ }^{1}$
}

\begin{abstract}
This article discusses various historiographies of spirituality as an indication of the influence of context on spirituality. It gives an overview of the most important historiographies of spirituality. Secondly, it describes the extremes of contextuality and noncontextuality, before finally reflecting on the dialectic tension between spirituality and contextuality.
\end{abstract}

The contextuality or historicity of spirituality is not self-evident. Not until modern times, in Europe, did it become more or less normal to look at spirituality from a historical perspective. It is thus not strange that the historiography of spirituality arose from the nineteenth century. In that time, the historical perspective was flowering in all sciences. This historical approach is so compulsive that almost everything that "happens" has to be "historicised". But we can ask ourselves whether this contextualisation, in its predominant and absolute sense, corresponds with the deeper spiritual reality.

This article first gives an overview of the most important historiographies of spirituality. Secondly, it describes the extremes of contextuality, and noncontextuality. Finally, it reflects on the dialectic tension between spirituality and contextuality.

\section{THE HISTORIOGRAPHY OF SPIRITUALITY}

Historicity was one of the main issues of the nineteenth century. All great historical syntheses were born in the late modernity of the WestEuropean mind. Examples of these were Marx's great draft of the history of economy as an all-compassing infrastructural determination of culture (spirituality included, belonging to the superstructure of history) and Hegel's phenomenology of the Spirit. The nineteenth century is also the century of the great syntheses of Biblical history:

1 K. Waaijman, Research Fellow, Department of New Testament, University of the Free State, Bloemfontein; and Head of the Titus Brandsma Institute, Nijmegen. 
the interpretation of Biblical texts within the all-compassing framework of a historical survey.

A fruit of the same spirit of the nineteenth century is the development of the historiography of spirituality. Three bridgeheads mark this development.

The first bridgehead into the historiography of spirituality is the work of Pourrat (1921-1930; cf. also Saudreau 1927). His La spiritualité chrétienne made history and boosted the study of spirituality.

The second bridgehead is the Histoire de la spiritualité of Bouyer (1960-1966), similarly a work in four volumes. In part one, Bouyer treated the spirituality of the New Testament and the Fathers; in part two, Le Clercq, Vandenbroucke and Bouyer described the spirituality of the Middle Ages; in part three, Bouyer described the spirituality of the Orthodox church, Protestants and Anglicans; and in part four, modern spirituality was described by Cognet. Striking in this series was that the Old Testament, Judaism, Islam, and ancient and indigenous spiritualities were absent, as was lay spirituality. The Historia de la Espiritualidad, again in four volumes, partly made up for this lack: it reflected awareness of extra-Christian forms of spirituality (Judaism, Islam, gnosis, Hellenism, and so forth) and of modern atheism (Flors 1969).

The third bridgehead became apparent with the reference work entitled World spirituality - An encyclopedic history of the religious quest (Cousin 1985-). This 25-volume reference work is subdivided into five sections: five volumes dealing with the indigenous spiritualities of Asia, Africa, Europe, Oceania and the three Americas (South, Central and North); fifteen volumes dealing with the spiritual traditions of the Far East (Hinduism, Buddhism, Taoism, Confucianism), the Middle East (Zoroastrianism, the Sumerian, Assyro-Babylonian and Hittite spiritualities) and the Mediterranean region (Egyptian, Greek, and Roman spiritualities), Jewish (including biblical), Christian and Islamic spiritualities; two volumes dealing with contemporary currents (esoteric and secular); the interreligious dialogue on the subject of spirituality; and a dictionary of world spirituality. These three bridgeheads are sur- 
rounded by monographs on periods, currents and persons, ${ }^{2}$ and by detail studies in compilations and periodicals. ${ }^{3}$

In Jewish spirituality the publication of Major trends in Jewish mysticism is still a high point (Scholem 1955), but not the end point. The historical research of Gershom Scholem, of which he gave accounts in a large quantity of publications, had its sequel in the works of numerous researchers: Katz, Dan, Idel, Jacobs, Green, Elior, Grözinger, Tishby, Lièbes, Schäfer, Grünwald, Halperin, Cohin, Werblowsky, and so forth.

From a Reformation point of view the situation is different. In 1917 , Preuss observed,

The history of Christian piety has not yet been written. Indeed, even the most essential preliminary studies for such a history are lacking (cf. Preuss 1917:1-2).

In 1995, Jaspert arrived at the same conclusion (cf. Jaspert 1995: 123-168), although several preliminary studies had by that time become available (cf. Nieden \& Nieden 1999).

A critical point in connection with this flood of historiographies is the question concerning the selection mechanisms which shape the historical reconstructions. Which stories are regarded as being less important? How has the story been divided? Where were the high points created? Which stories were written from the top down? On what grounds? The underlying question is, of course: From what perspective (and that always means, from the standpoint of what interest?) has the history been constructed? (cf. Sheldrake 1991). It is striking, for example, to see the pains which Pourrat and Bouyer take to make the history of Christian spirituality a sign of unity: to them all the differences remain expressions of one and the same (Catholic) mind. Also Greek-Latin dominance at the expense of national spiritualities is accepted as self-evident. The perspective is preponderantly clerical and

2 For a brief overview of the most important works, cf. Steggink \& K. Waaijman (1985:117-120; Mataniç 1990:162-170).

3 See section 6: Geschiedenis van de spiritualiteit, in Bibliographia Internationalis Spiritualitatis a Pontificio Instituto Spiritualitatis (BIS); the Index of articles on Jewish studies (RAMBI) under Spiritual Trends in Judaism; the bibliography in the Revue d'Histoire Ecclésiastique and the Revue d'Histoire de la Spiritualité (1920-1978). 
monastic. The newer overviews (e.g. The study of spirituality and world spirituality) practise greater openness, do not proceed from a specific theological framework and are more aware of cultural plurality (Sheldrake 1991:83-104). These newer overviews, however, will also prove to be guided by a time-bound perspective.

A history of spirituality is a story, and a story omits and includes, brings to the fore and shifts into the background. A history is said to originate in this diachronic fashion - which creates the impression that its course was necessarily thus and not otherwise. The facts, though, frequently fail to show such a coherent sequence. Shaping the history is expressing the convictions of a particular tradition. The historical syntheses mostly serve as a perspective which confirms the interests of the historiography. They are part of the tradition, which they describe. They belong to their tradition, even when they criticise it.

\section{THE QUESTION OF CONTEXTUALITY}

After more than a century of historiography, the question is still: How closely is spirituality tied in with the (reconstructed) context or how far is it kept away from it? In recent times two extremes have been observed. The one extreme stresses especially the continuity between spirituality and its historical context; the other extreme emphasises the difference.

At the one extreme is the tendency to read spirituality in terms of its socio-cultural context: the dominant Zeitgeist, the political-economic relations, the religious institutions, and so forth. People read the "life" of Teresa of Avila in the light of her time. In that case a number of lines become visible that mark her spiritual growth: her marginalised and banished Jewish background; the dominant religious consciousness of the hey-day of the Catholic Spanish counter-reformation; the maledominated society in which Teresa functioned as a woman; the importance of affective relations in the context of a rigorously ordered monastic celibate lifestyle; the uncertainty which the discovery of new worlds laid bare; the prevailing scholastic theology which necessitated "new words"; the threat of the Inquisition; the desire for religious renewal; the need for a return to the "Origin"; and so forth. Here the "life" of Teresa is made intelligible in the light of "her time" (Steggink 1968; 
Steggink \& Efrén de la Madre de Dios 1982-1984). In a comparable way the rise of Hasidism can be read against the background of the economic circumstances in which Eastern-European Jews found themselves and the bankruptcy of Jewish mysticism after the public activities of Sabbatai Zwi. One can interpret Teresa of Lisieux from the perspective of the bourgeois milieu of nineteenth century France.

Historical research in spirituality also knows the other extreme of the continuum: spirituality, especially in its mystical component, differs from its context. There is discontinuity between the socio-cultural context and the phenomenon of spirituality. We can make this discontinuity concrete with the aid of the "historical definition of mysticism" proposed by Dan (1993:58-90). On the basis of his research in Jewish mysticism he arrives at the conclusion

that mysticism as a historical phenomenon in "book" religions can generally be characterized only in negative terms: rejection of the senses and logic as denoting divine truth; rejection of accepted exegetical methodologies as providing insights into divine intentions; rejection of communicative language as an instrument of conveying supreme truth; and, usually, a critical attitude, overt or implied, concerning rituals and social norms of the religious culture. In many cases, a rebellious attitude can be discerned (Dan 1993:89).

Only on the basis of this discontinuous relation to the socio-religious context can one cautiously proceed to discover some contingent similarities between the various mystical figures and currents.

\section{THE DIALECTIC BETWEEN SPIRITUALITY AND CONTEXTUALITY}

Finally it is necessary to articulate an own position regarding the contextuality of spirituality. In my opinion there is a dialectic relation between spirituality and the socio-cultural context. Continuity and discontinuity between spirituality and the socio-cultural context are extremes in a field of tension. De Certeau (1966:3-31) has strikingly described this field of tension. On the one hand, spirituality expresses itself in the language of a certain period, a reality by which its search for God gains form and content:

The essential element in any spiritual experience is not some "otherness" quite outside the language of the time. This very language is 
what the spiritual man takes seriously; it is in this very cultural situation that his yearnings and his predicament "take flesh"; it is through this medium that he finds God, yet ever seeks him, that he expresses his faith, that he carries on simultaneous experiments in colloquy with God and with his actual brothers (idem 9).

On the other hand, that same spirituality eludes the cultural language in which it expresses itself. It cannot find the words needed; it is unsayable. Lived spirituality cannot express itself in the language of the time. The language of the culture falls short. For that reason, spirituality speaks of the Inexpressible. It is precisely in this "Unsayable" that spirituality expresses itself most sharply. In reality, this "constitutes" the specific discourse of spirituality (idem 9, 17). Spirituality seeks out the culture but at the same time experiences that it cannot fully express its core in it:

When he launches out in full faith and with all his heart into human history, he is surprised that he is met with a "vacuum," as much on the part of religious teaching as in the activities and the knowledge which could yet, in a given situation, provide a meeting point with God (idem 18-19).

The spiritual experience, which in terms of its core is inexpressible, strives to achieve consciousness from within this non-sayability in structures of experience and to express itself in the language of the culture. The tragic reality is that this striving alienates spirituality from its tradition:

For the solitude of the Christian over against his own tradition is the reverse side of a certain solidarity, a sharing in a kind of language that has not been put into Gospel terms. The "spiritual person's" disappointment is expressed in a language that has not yet acquired or created its Christian punctuation (idem 20).

The relation between this particular spiritual form and the historical context is paradoxical: on the one hand, spirituality speaks the language of the culture of which it is a part; on the other hand, it distances itself from the cultural language because it is incapable of expressing the spiritual experience. At the same time, this tension makes the relation to the tradition problematic: to the extent that spirituality engages itself more deeply with the culture, to the degree that it alienates itself from the tradition out of which it lives and which it must, therefore, rediscover. 


\section{BIBLIOGRAPHY}

AARNINK L et al.

1998. Geest en tijdgeest. Speling 50:4.

BERG D (ED.)

1993. Spiritualität und Geschichte. Werl.

BOYER L et al.

1960-1966. Histoire de la spiritualité chrétienne. Paris.

Cousins E (ED.)

1985-. World spirituality. An encyclopedic history of the religious quest. New York.

DAN J

1993. In quest of a historical definition of mysticism. Studies in Spirituality 3:58-90.

DARricau R \& Pyerous B

1991. Histoire de la spiritualité. Paris.

\section{De Certeau M}

1966. Cultural and spiritual experience. Spirituality in the secular city. New York.

Concilium 19.

\section{DinZELBACHER P}

1994. Christliche Mystik im Abendland. Ibre Geschichte von den Anfängen bis zum Ende des Mittelalters. Paderborn.

\section{FARRE L}

1988. Breve historia de la espiritualidad. Buenos Aires.

FLORS J (ED.)

1969. Historia de la Espiritualidad I-IV. Barcelona.

JASPERT B

1995. Frömmigkeit und Kirchengeschichte. In: Jaspert 1995:123-168.

JASPERT B (HRSG.)

1995. Frömmigkeit. Gelebte Religion als Forschungsaufgabe. Paderborn.

Jimenez Duque B \& Sala Balust L

1969. Historia de la espiritualidad. Barcelona.

HOLLENBACK J

1980. Mysticism. A comparative historical study. Ann Arbor.

\section{Homes U}

1980. A bistory of Christian spirituality. An analytical introduction. New York. 


\section{Magill F \& MCGreal I}

1988. Christian spirituality. The essential guide to the most influential spiritual writings of the Christian tradition. San Francisco.

MATANIÇ A

1990. La spiritualitá come scienza. Milano.

\section{MCGINN B}

1991-1998. The presence of God. A history of Western Christian mysticism. New York.

MOLINER J

1972. Historia de la espiritualidad. Burgos.

Nieden H \& Nieden M

1999. Praxis pietatis. Stuttgart et al.

\section{Pablo Maroto D}

1986. Historia de la espiritualidad. Madrid.

\section{PACHO E}

1984. Storia della spiritualità moderna. Roma.

\section{Preuss $\mathrm{H}$}

1917. Luthers Frömmigkeit. Leipzig.

\section{POURRAT P}

1921-1930. La spiritualité chrétienne. Paris.

\section{ROYO MARIN A}

1973. Los grandos maestros de la vida espiritual. Historia de la espiritualidad cristiana. Madrid.

\section{RUH K}

1990-1993. Geschichte der abendländischen Mystik. München.

\section{SAUdREAU A}

1927. La piété à travers les âges. Paris.

\section{SCHOLEM G}

1955. Major trends in Jewish mysticism. London.

\section{SHELDRAKE P}

1991. Spirituality and history. Question of interpretation and method. London-New York.

\section{STEGGINK O}

1968. Tiempo y vida de Santa Teresa. Madrid.

Steggink O \& Efrén De la Madre de Dios

1982-1984. Santa Teresa y sy tiempo I-II. Salamanca.

Steggink O \& WaAjuman K

1985. Spiritualiteit en mystiek 1. Inleiding. Nijmegen. 
Waaijman

Keywords

Spirituality

Contextuality

Historiography
Spirituality and contextuality

Trefwoorde

Spiritualiteit

Kontekstualiteit

Historiografie 